\title{
Anatomy of myxospermic diaspores of selected species in the Succulent Karoo, Namaqualand, South Africa
}

\author{
H. FOTOUO MAKOUATE*, M.W. VAN ROOYEN*† and C.F. VAN DER MERWE**
}

Keywords: arid regions, diaspores, dispersal, myxospermy, Namaqualand, scanning electron microscopy, Succulent Karoo

\section{ABSTRACT}

\begin{abstract}
Environmental conditions encountered in arid ecosystems differ vastly from those in more mesic ecosystems. Dispersal strategies in arid environments reflect these differences and many mechanisms have evolved that restrict or hinder dispersal. Myxospermy is a trait developed by plant species from arid regions to restrict diaspore dispersal by means of an anchorage mechanism. Several of the abundant plant species in Namaqualand, within the arid Succulent Karoo Biome, display myxospermy. Diaspores of these species produce copious amounts of mucilage when they are moistened and are anchored to the soil once the mucilage dries out again. This study investigated the origin of the mucilaginous layer of 12 species anatomically, using both light and scanning electron microscopy. The mucilage production of the species investigated could best be grouped into three types: 1 , epidermal and sub-epidermal cells of seeds and achenes; 2 , specialized tissue in wings or the pappus of achenes; and 3, mucilage excreting hairs. Previous systems for classifying the different types of mucilage production did not recognize the mucilaginous nature of wings or a pappus. A short note on the composition of the mucilage is included.
\end{abstract}

\section{INTRODUCTION}

Plants have developed many functional traits that allow them to adapt and survive in different environments. Seed dispersal is an important functional trait that influences the population structure and the spatial and temporal turnover of species within a plant community. Myxospermy is the phenomenon where the epidermis of the diaspore (seed/fruit) contains mucilaginous cells, which swell and become sticky when in contact with water (Gutterman \& Shem-Tov 1997; Van Rheede van Oudtshoorn \& Van Rooyen 1999). Myxospermy is classified as an antitelechoric dispersal mechanism and is encountered more often in arid than in mesic environments. The original explanation for the prevalence of antitelechory in desert environments was that these mechanisms were adaptive responses to the particularly high mortality of dispersed seeds in deserts and that they had evolved as mechanisms to reclaim the mother site (Murbeck 1919; Zohary 1937; Stopp 1958; Ellner \& Shmida 1981; Van Rooyen et al. 1990). Ellner \& Shmida (1981) however, argued that antitelechory was a side effect of characters whose adaptive value was not directly related to dispersal. Among the benefits derived from antitelechory are the spreading of germination over time and the provision of suitable conditions for germination and subsequent seedling establishment.

There are many divergent ideas about the ecological importance of myxospermy, and it probably fulfils various functions. When wet, myxospermic diaspores adhere to the soil; and after drying out, remain glued to soil particles and thus resist being carried to unfavourable locations by wind. However, wet diaspores can also adhere to the feet or fur of animals and be dispersed zoochorically. The good contact between the mucilage layer and the soil surface increases water absorption for germination,

\footnotetext{
* Department of Plant Science, University of Pretoria, 0002 Pretoria † gretel.vanrooyen@up.ac.za.

** Laboratory for Microscopy and Microanalysis, University of Pretoria, 0002 Pretoria.

MS. received: 2010-01-15.
}

and as a result, myxospermic species germinate more successfully on the surface of the soil than non-myxospermic species (Bregman \& Graven 1997; Zaady et al. 1997; Van Rheede van Oudtshoorn \& Van Rooyen 1999). The water held by the mucilage could also serve as a water reservoir for seedling establishment (Gutterman et al. 1967; Gutterman 1993, 1996), although this function of the mucilage has been challenged (Murbeck 1919; Grubert 1974). Furthermore, the adherence of the seed to the soil by the mucilage prevents massive collection by seed predators (Gutterman 1993), and the repeated wetting of mucilaginous seeds during many nights with dew may affect the repair mechanisms of the DNA, cell membranes, and organelles; thereby enhancing seed viability for many years (Osborne et al. 1980/1981; Leprince et al. 1993; Huang et al. 2008). The mucilage has also been reported to have a stimulatory action on germination (Gat-Tilman 1995) or it may control the germination process by excluding the passage of oxygen when there is excess moisture (Gutterman et al. 1967, 1973; Gutterman 1996; Tamara et al. 2000).

Although several studies have drawn the attention to the ecological importance of myxospermy in the flora of Namaqualand (Rösch 1977; Van Rooyen et al. 1990; Van Rheede van Oudtshoorn \& Van Rooyen 1999), the germination behaviour of myxospermic species (Fotouo Makouate 2008) and the response of myxospermic species to grazing pressure (Fotouo Makouate 2008), little attention has thus far been given to the origin and chemical composition of the mucilage of these myxospermic diaspores. The objectives of this study were to investigate the origin and the chemical composition of the mucilage of a representative sample of myxospermic species in Namaqualand, South Africa.

\section{STUDY AREA AND SPECIES}

Diaspores of the species investigated in this study were all collected in the Namaqualand Hardeveld Bioregion of the Succulent Karoo (Mucina \& Rutherford 
2006). The Succulent Karoo is an arid winter rainfall region stretching along the West Coast of South Africa and Namibia; and is recognized by the IUCN as one of only two entirely arid global hotspots of biodiversity (Conservation International 2009). Many of the biologically unique features of this biome have been attributed to its climate, i.e. the effective and relatively predictable seasonal rainfall, and the relatively moderate winter temperatures (Mucina \& Rutherford 2006). A prominent feature of the Namaqualand Hardeveld Bioregion is the extravagant spring floral display of winter-growing annuals (Van Rooyen 1999).

Representative species of four families were investigated: within the Lamiaceae, the perennial shrub Salvia dentata; within the Acanthaceae, two dwarf perennial shrubs Acanthopsis horrida and Blepharis furcata; within the Brassicaceae, the annual Heliophila thunbergii var. thunbergii; and within the Asteraceae, the perennial shrubs Pentzia incana and Othonna cylindrica as well as the annual species Cotula barbata, Monoculus (Tripteris) hyoseroides, Senecio arenarius, Ursinia cakilefolia, Oncosiphon grandiflorum and Foveolina dichotoma.

\section{MATERIALS AND METHODS}

\section{Scanning electron microscopy (SEM)}

Dry seeds/achenes were mounted on a stub and made conductive with $\mathrm{RuO}_{4}$ vapour (Van der Merwe \& Peacock 1999). For wet samples, seeds/achenes of each species were soaked in water for 24 hours before fixation. Seeds/achenes were then fixed in $2.5 \%$ glutaral-

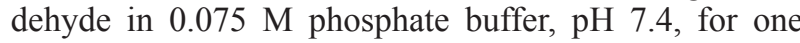
hour, and rinsed three times (five minutes per rinse) in $0.075 \mathrm{M}$ phosphate buffer and dehydrated in an ethanol series with the respective concentrations of $30 \%, 50 \%$, $70 \%, 90 \%$, and $100 \%$. This was followed by critical point drying in liquid $\mathrm{CO}_{2}$, whereafter the seeds/achenes were mounted on a stub and made conductive with $\mathrm{RuO}_{4}$ vapour. Samples were viewed with the use of a JSM $840^{4}$ scanning electron microscope (SEM) (JEOL, Tokyo, Japan), and photographs were taken with the computer program Orion 6.60.4.

\section{Light microscopy}

Further studies were done on diaspores where the origin of the mucilage could not be clearly established with the aid of an SEM. Dry samples were fixed in 4\% $(\mathrm{v} / \mathrm{v})$ formaldehyde in $50 \%(\mathrm{v} / \mathrm{v})$ ethanol (FAA) to prevent mucilage release. The wet samples were immersed in water for 24 hours. Wet samples were fixed in $2.5 \%$ glutaraldehyde in $0.075 \mathrm{M}$ phosphate buffer, $\mathrm{pH} 7.4$, for one hour, and rinsed three times (five minutes per rinse) in $0.075 \mathrm{M}$ phosphate buffer, and dehydrated in an ethanol series with the respective concentrations of $30 \%$, $50 \%, 70 \%, 90 \%$ and $100 \%$. Samples were subsequently infiltrated over two days with pure LR-White resin and polymerized at $65^{\circ} \mathrm{C}$ for 24 to 36 hours. Sections were cut with a Reichert Ultracut E microtome. Each section was stained, mounted in immersion oil, and viewed with a Nikon Optiphot light microscope (LM) (Tokyo, Japan). Photographs were taken with a Nikon Digital camera DXM 1200 (Tokyo, Japan) and the computer program Nikon ACT-1 (Tokyo, Japan).

Diaspore staining was done according to various manuals of microscopic staining (McClean \& Ivimey Cook 1941; O’Brien \& McCully 1981; Lawton \& Ettridge 1986). Seven different stains were used to test for the presence of various compounds, the details of which are given in Table 1.

TABLE 1.- Stains used for various compounds and expected results

\begin{tabular}{l|l|l}
\hline Stain & Compound & Expected results \\
\hline Aniline blue & Callose & Blue \\
Biuret solution & Protein & Violet \\
Methylene blue & Cellulose & Blue \\
Phloroglucinol & Lignin & Pink \\
Ruthenium red & Pectic substances & Red \\
Sudan 4 & Lipids & Yellow \\
Toluidine blue & Polysaccharides & Pink-purple \\
\hline
\end{tabular}

RESULTS AND DISCUSSION

\section{Anatomical investigation}

On the basis of the anatomical origin of the mucilage, Zohary (1937) distinguished seven different types. Grubert (1974) recognized many more types, but his three main categories were based on whether the origin was 1 , restricted to epidermal structures, e.g. epidermis or hairs; 2, from epidermal and sub-epidermal layers; or 3, restricted to sub-epidermal layers.

Neither the classification systems of Zohary (1937) or Grubert (1974) accommodate diaspores where the mucilage production occurs on wings of achenes, as was reported in the present study. In general, diaspores of most myxospermic species are smooth-coated and do not contain obvious appendages to advance telechory. Contrary to the belief that none of the myxospermic Asteraceae possess a pappus (Grubert 1974), many myxospermic species from Namaqualand are winged or possess a winged pappus. The presence of wings would allow anemochoric dispersal during phase I dispersal (Chambers \& MacMahon 1994), but further anemochoric dispersal would be prevented once the achenes were moistened and remained attached to soil particles.

The mucilage production of the species investigated in the present study could best be grouped into three main types:

1 Epidermal and sub-epidermal cells of seeds and achenes:

1.1 Cells of seeds bursting only in the centre

1.2 Cells of achenes bursting across the entire surface

2 Specialized tissue in wings or pappus of achenes

3 Hairs:

3.1 On achenes

3.2 On seeds

\section{Epidermal mucilage}

Heliophila thunbergii var. thunbergii (Brassicaceae) 

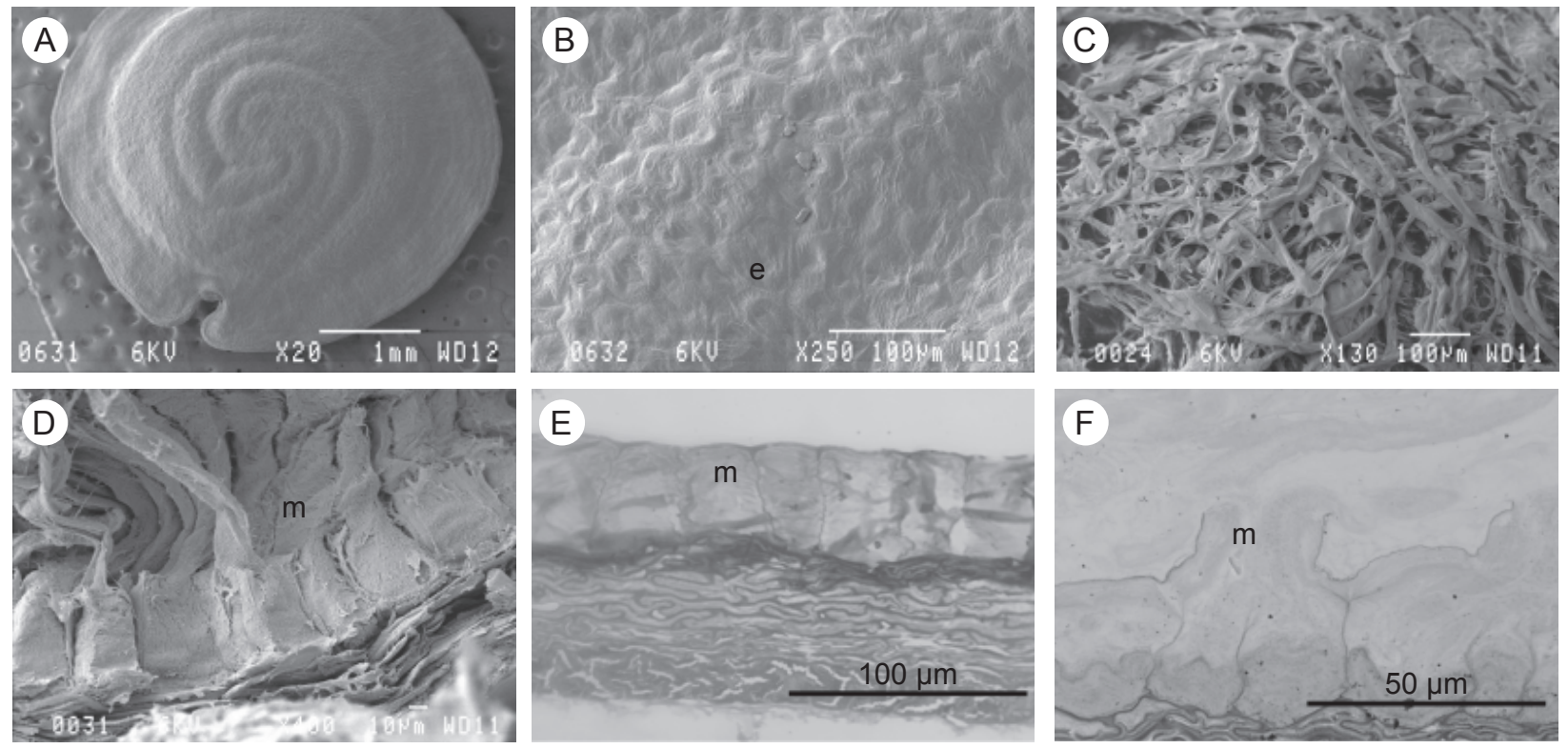

FIGURE 1.-Heliophila thunbergii var. thunbergii, seeds. A-D, SEM: A, entire dry seed; B, high magnification of dry epidermis; C, high magnification of wet seed surface; D, section of wet seed. E, F, LM: E, section of the dry seed; F, cross section of wet epidermis. e, epidermal layer, $\mathrm{m}$, mucilage.

The scanning electron micrograph of dry seeds of H. thunbergii var. thunbergii reveals a circular seed (Figure 1A). The epidermal layer (e) consists of circular cells with a raised margin and a cavity in the centre (Figure 1B). Upon wetting, the mucilage swells and the epidermal cells become incapable of containing the excess mucilage and therefore rupture. Once wet, the seed is covered by a gelatinous film (Figure 1C), similar to the mucilaginous seed coat of two species of the Brassicaceae described by Gutterman \& Shem-Tov (1997). The thin section of the dry seed also reveals the epidermal cells filled with mucilage (m) (Figure 1E). The section of the wet seed reveals the epidermis with ruptured cells from which filaments of mucilage (m) emerge (Figure 1D, F).

\section{Salvia lanceolata (Lamiaceae)}

A similar pattern was observed for the seeds of S. lanceolata (Lamiaceae). Once in contact with water, the outer layer of the epidermis absorbs water quickly, the epidermis cells swell, the cuticle ruptures and the contents are excreted as long, continuous threads. Hedge (1970) reported that the contents of the epidermis cells of some Lamiaceae are secreted in the shape of long, continuous, helically coiled threads.
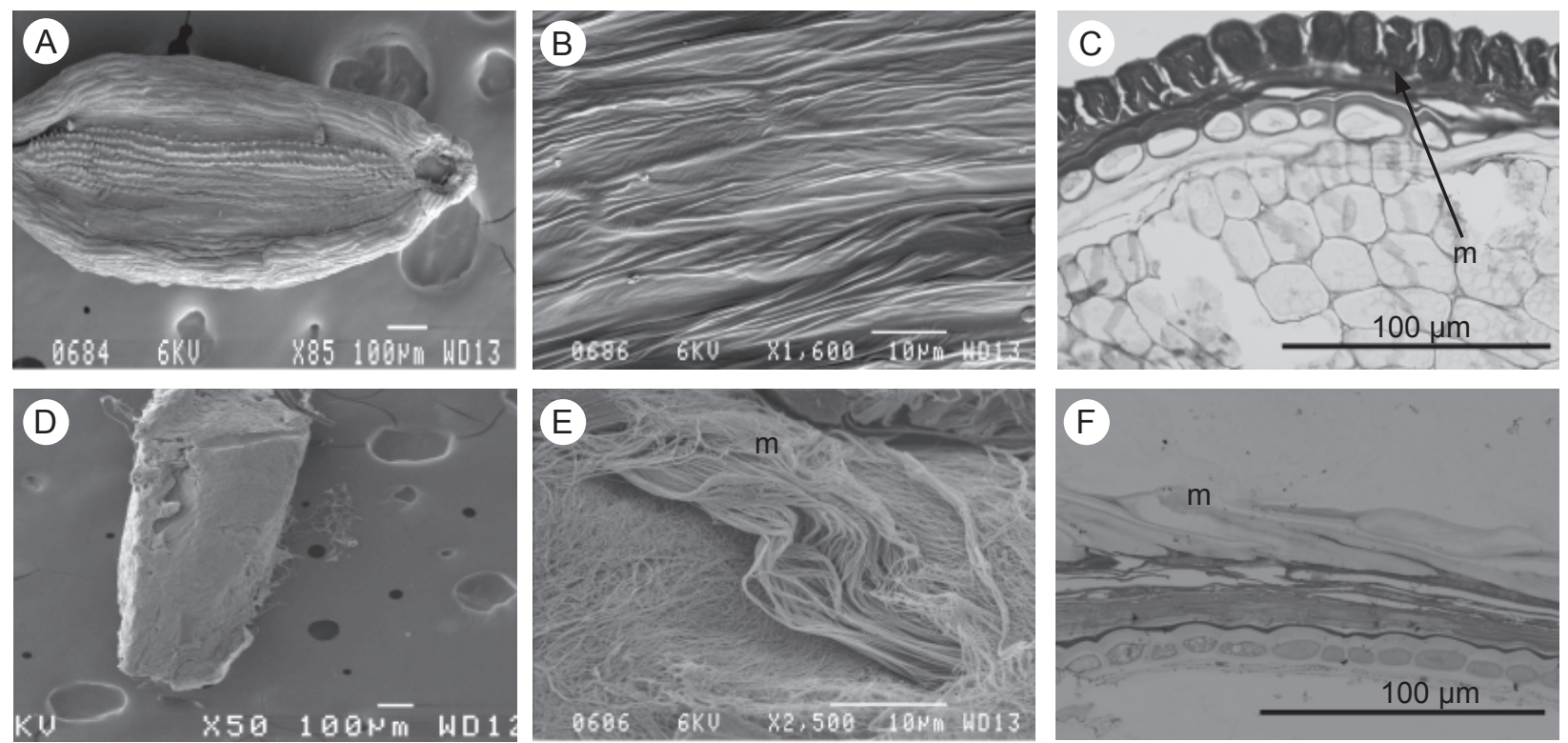

FIGURE 2.-Cotula barbata, achenes. A, B, D, E, SEM: A, entire dry achene; B, high magnification of the epidermis; D, entire wet achene; E, high magnification of wet epidermis covered with thick layer of mucilage. C, F, LM: C, cross section of dry achene coat, with mucilage (arrow) retained in epidermal layer; F, cross section of wet epidermis of which outer layer has burst, releasing mucilage from epidermal cells. m, mucilage. 

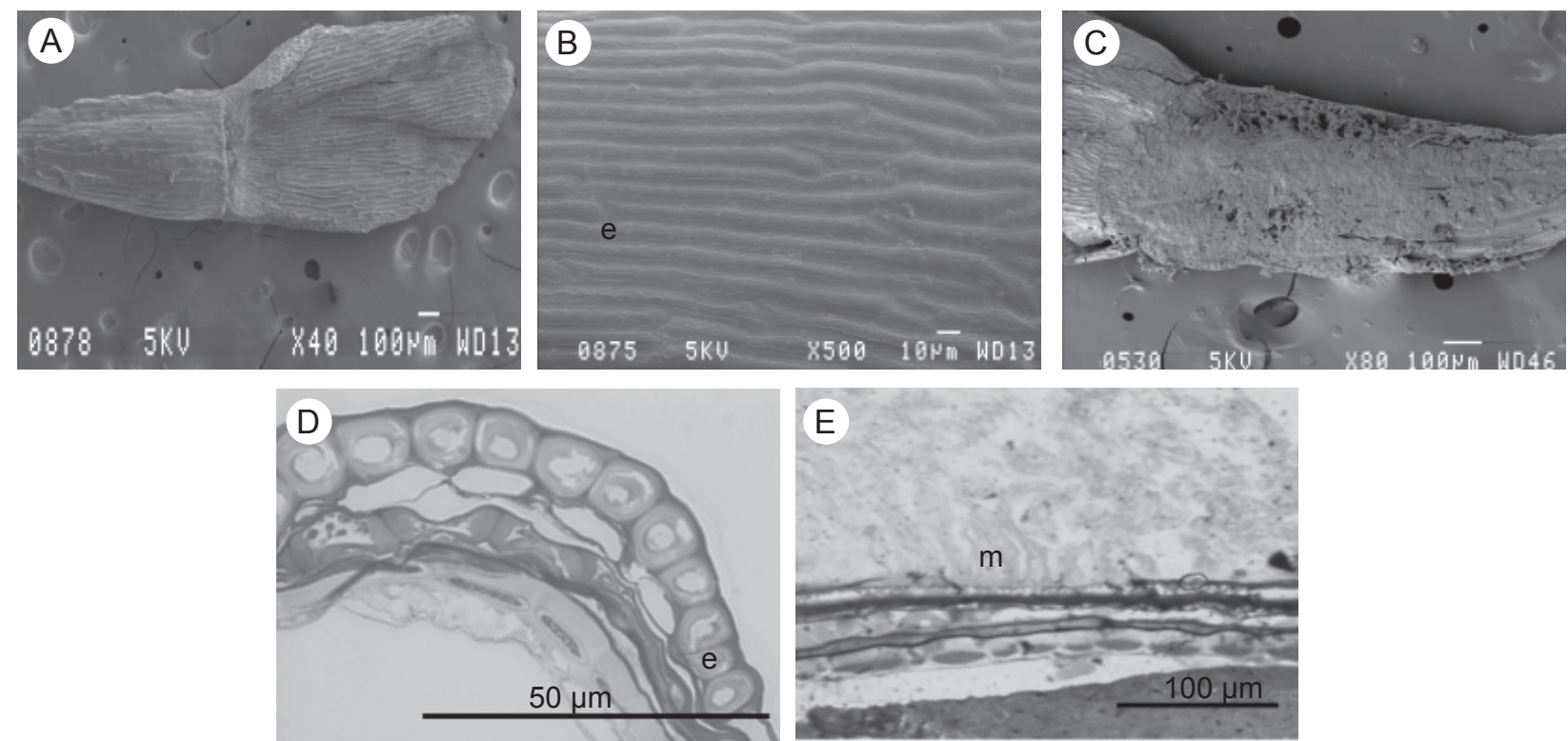

FIGURE 3.-Foveolina dichotoma, achenes. A-C, SEM: A, entire achene of $F$. dichotoma; B, high magnification of the epidermis of $F$. dichotoma; C, wet achene. Oncosiphon grandiflorum, achenes: D, E, LM: D, thin cross section of dry epidermis; E, thin cross section of wet epidermis with broken epidermal cells that liberate mucilage. e, epidermal layer, m, mucilage.

\section{Cotula barbata (Asteraceae)}

In the dry state, the one side of the achene of C. barbata is undulated (Figure 2A), whereas the other side of the achene is smooth (Figure 2B). The mucilage structure observed in C. barbata is similar to that of H. thunbergii var. thunbergii with the mucilage contained in the epidermal layer (Figure 2C). When C. barbata achenes come into contact with water (Figure 2D), the epidermal cells burst across the entire outer surface (Figure 2E, F) and not only the centre of the cell as in the case of H. thunbergii var. thunbergii.
Foveolina dichotoma, Oncosiphon grandiflorum and Pentzia incana (Asteraceae)

These three species are taxonomically closely related, and it appears that they have the same way of producing mucilage. The SEMs show that the epidermis of the dry achenes of $F$. dichotoma consists of parallel longitudinal cells (Figure 3A, B), as was also found for O grandiflorum and P. incana. Following wetting, fixation, and critical point drying, the achenes are covered with a gelatinous film but the pappus remains unchanged (Figure 3C). Light microscope sections of the dry achene of $O$. grandiflorum show that the epidermal cells are filled
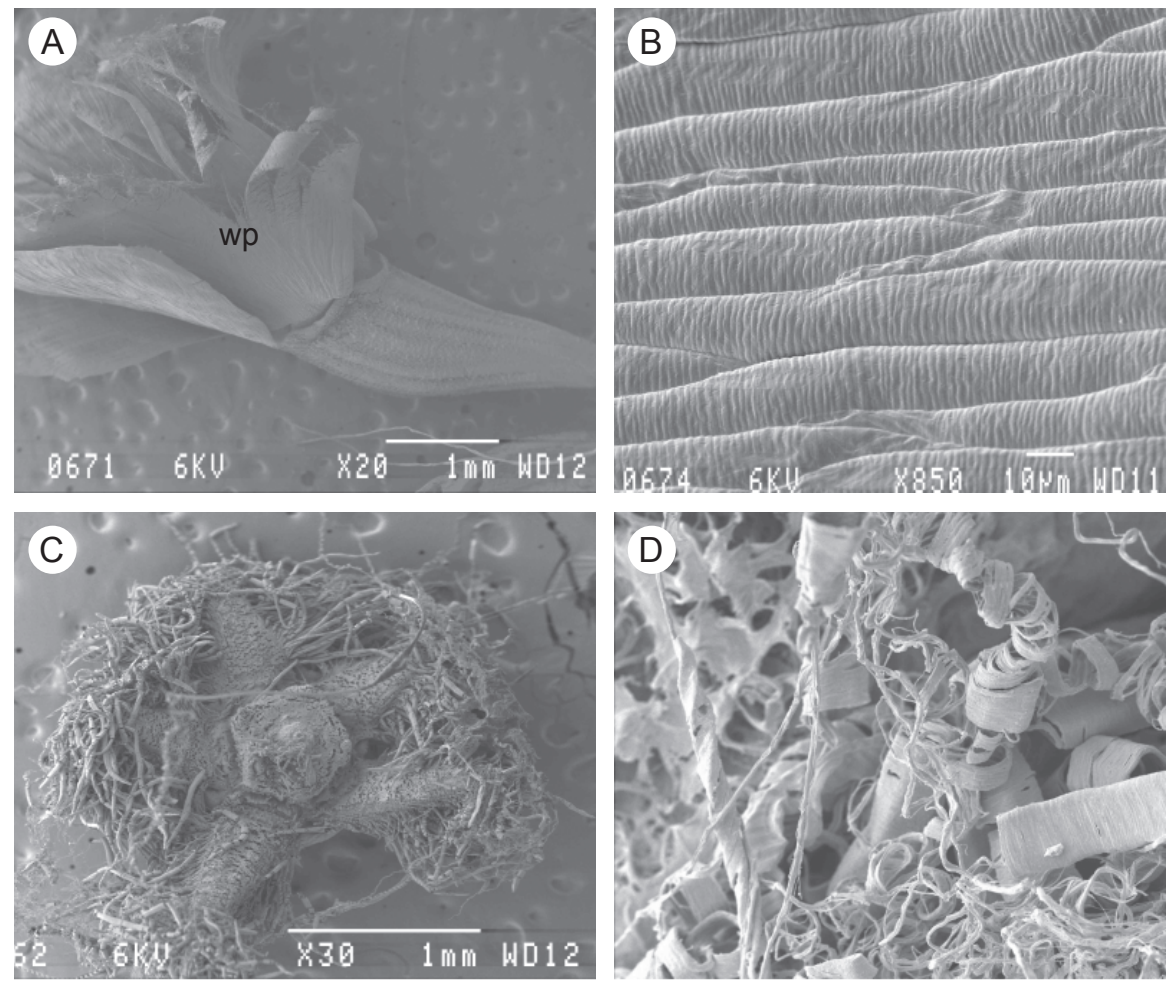

FIGURE 4.-Ursinia cakilefolia, SEM of achenes: A, entire dry achene with winged pappus; B, high magnification of dry winged pappus consisting of radially elongated cells; C, entire wet achene with uncoiled winged pappus; $\mathrm{D}$, high magnification of wet winged pappus showing long strands of uncoiled mucilage. wp, winged pappus. 

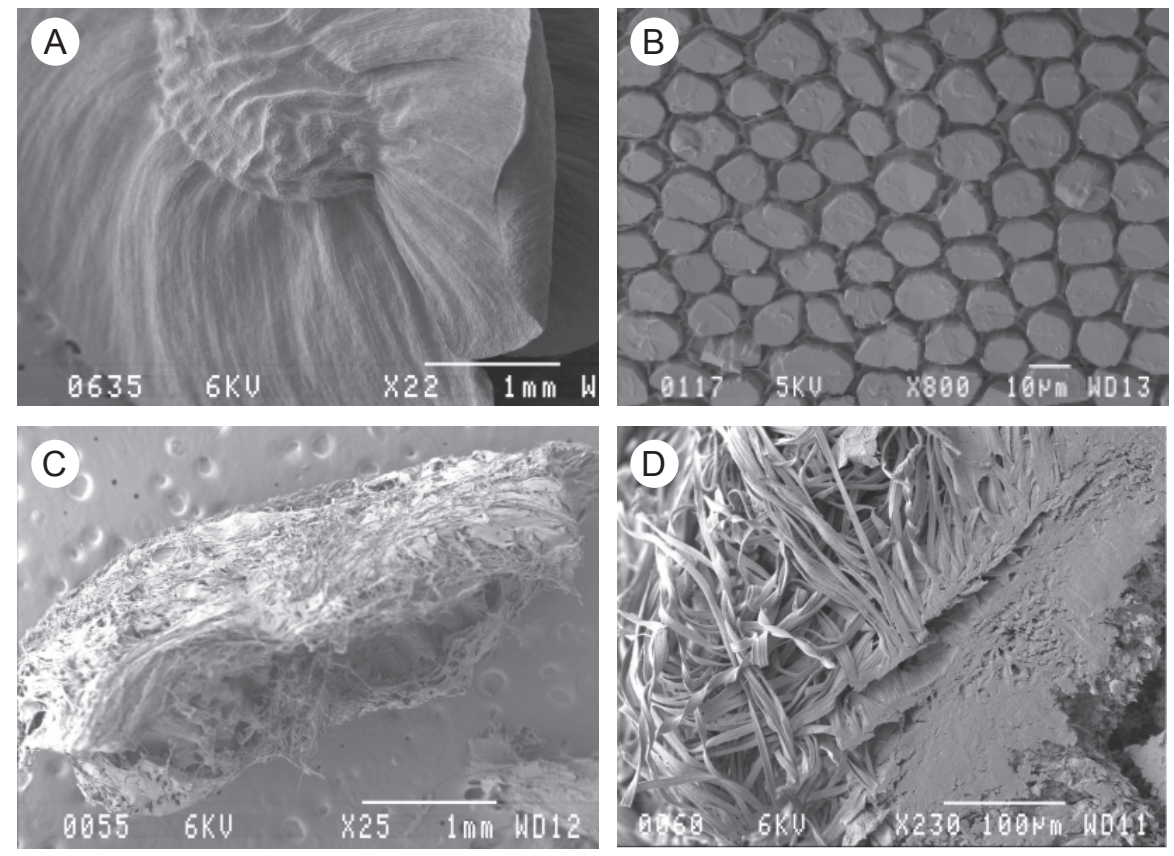

FIGURE 5.-Monoculus hyoseroides, SEM of achenes: A, entire dry achene; B, high magnification of a section of the wing; $\mathrm{C}$, entire wet achene with disintegrated wing; D, high magnification of long strands of mucilage.

with mucilage (Figure 3D), which is released when the cells burst open upon swelling in contact with water (Figure 3E).

\section{Mucilaginous wings}

\section{Ursinia cakilefolia (Asteraceae)}

Dry achenes of $U$. cakilefolia have a winged pappus (wp) (Figure 4A), consisting of a single layer of radially elongated cells with helically thickened cell walls (Figure 4B). When the pappus comes into contact with water, the cells separate at the middle lamellae and the helical thickenings uncoil to form long strands of mucilage (Figure 4C). The different steps through which the pappus uncoils are clearly visible under the SEM (Figure 4D). The same process was observed in $U$. nana subsp. nana (Rösch 1977).

\section{Monoculus hyoseroides (Asteraceae)}

Achenes of $M$. hyoseroides are three-winged. The epidermis of the seed-bearing part of the achene is undulate and does not become mucilaginous (Figure 5A). The section through the wings shows hexagonally shaped cells completely filled with mucilage and separated by thick cell walls (Figure 5B). Upon wetting, the cells separate and the wings become completely mucilagi- nous (Figure 5C) and the long mucilage strands remain attached to the achene (Figure 5D).

\section{Mucilaginous hairs}

\section{Senecio arenarius (Asteraceae)}

In the dry condition, the shiny white hairs (h) have a finger-like shape and lie against the achene surface (Figure 6A, B). The interior of the hair seems to be filled with a coiled thread as seen at high magnification (Figure 6B). In the wet condition, the hairs spread \pm at right angles to the seed. Apparently, when the mucilaginous hairs absorb water the threads uncoil and become thin and long (Figure 6C). The same phenomenon was observed for Othonna cylindrica, as well as for O. floribunda (Rösch 1977).

Acanthopsis horrida and Blepharis furcata (Acanthaceae)

In the dry condition, the hairs on the seed surface of $A$. horrida (Figure 7A, B) and B. furcata are tightly appressed to the seed coat and are covered with a thick deposit (Figure 7C). At high magnification it can be seen that these hairs contain coiled spirals (Figure 7B). Once in contact with water the thick deposit expands, the hairs become swollen and spread \pm at right angles to the seed
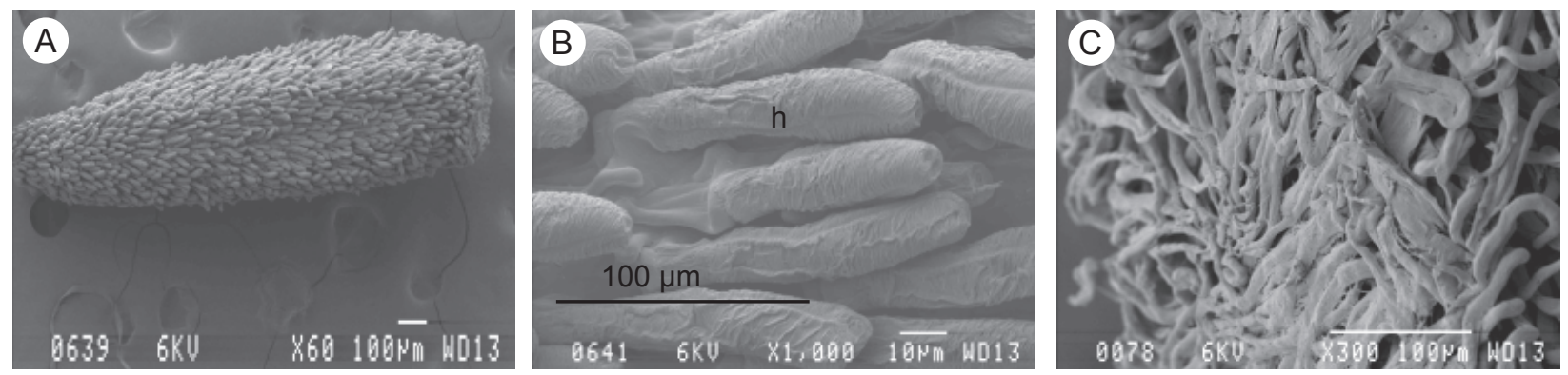

FIGURE 6.-Senecio arenarius, SEM of achenes: A, entire dry achene; B, high magnification of dry achene with hair lying against it; C, high magnification of wet hairs. h, hair. 

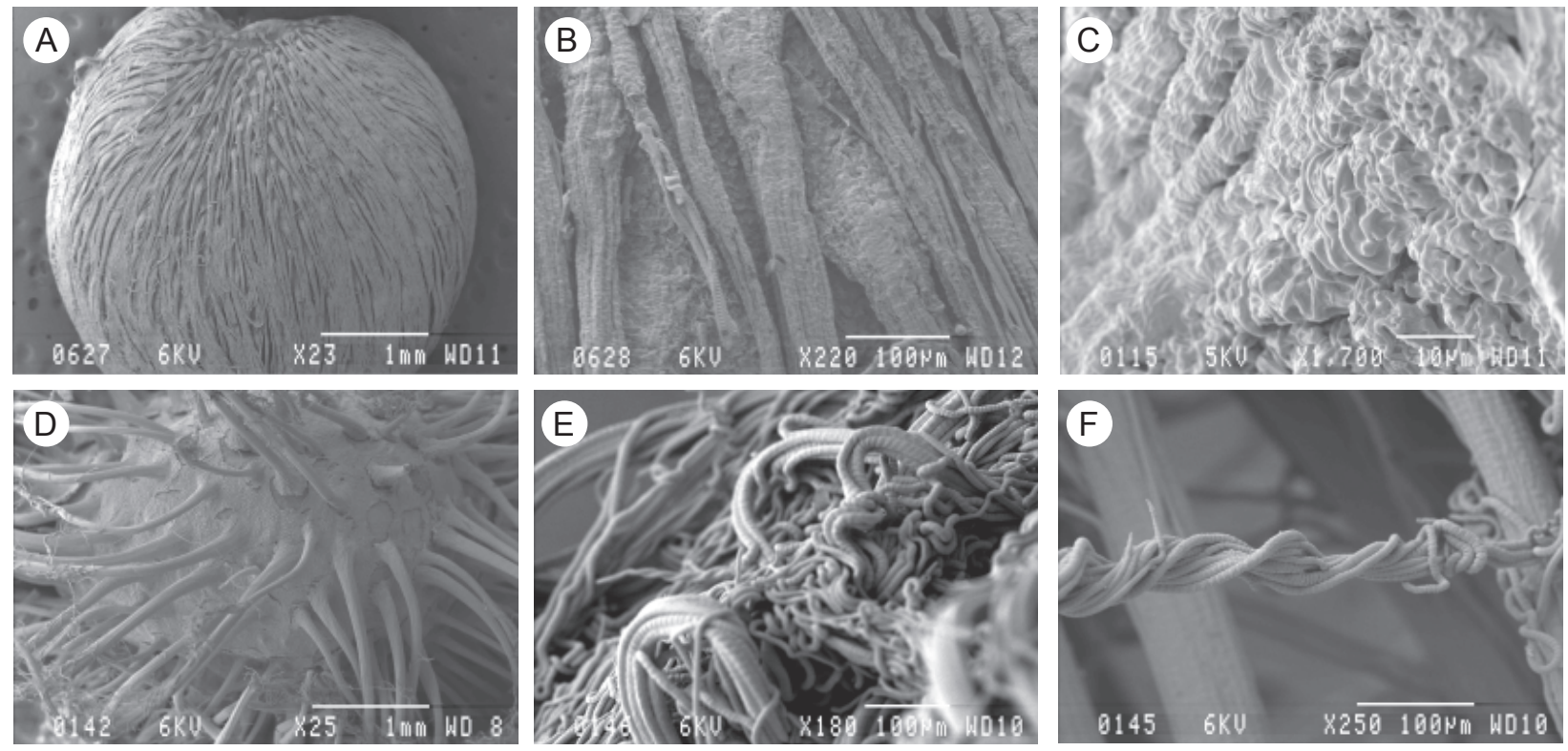

FIGURE 7.-Acanthopsis horrida, SEM of seeds: A, entire dry seed; B, hairs; C, dry epidermis covered with thick deposit; D, wet seed; E, swollen hairs; F, uncoiled strands of mucilage.

coat (Figure 7D). The tips of the hairs break open and release a multitude of strands of mucilage (Figure 7E, F).

\section{Chemical composition}

Three stains reacted positively with the mucilage of all species: methylene blue, ruthenium red, and toluidine blue; thus confirming the presence of polysaccharides such as cellulose and pectic substances. On the basis of the intensity of the reaction, the epidermal mucilage seemed to contain less cellulose than the mucilaginous wings and mucilaginous hairs. In some species, a slight reaction was also observed with aniline blue, indicating the presence of callose in the mucilage.

Cellulose is the most abundant plant polysaccharide found in the form of microfibrils in cell walls and mucilage. Dry amorphous and fibrous cellulose can absorb considerable amounts of water and becomes soft, flexible, and viscous. Pectin is a heterogeneous grouping of acidic structural polysaccharides with the main molecules being the D-galacturonic acid residues. They do not possess exact structures and are complex. As for cellulose, pectin is a water binder, is highly viscous, and can form a firm gel when in contact with water. In all cases, the mucilage of the diaspores investigated contained both cellulose and pectic substances. This could be due to the presence of microfibres of cellulose embedded in the pectin compounds forming a complex matrix. Both pectic substances and cellulose were also reported in the seed mucilage of Arabidopsis thaliana (Brassicaceae) (Windsor et al. 2000; Willats et al. 2001; Macquet et al. 2007). In a detailed chemical and macromolecular study of the composition of $A$. thaliana seed mucilage (Brassicaceae), Macquet et al. (2007) found that the mucilage was made up of two layers: a watersoluble layer that could be separated from the seed and an inner layer that remained firmly attached to the seed. The inner layer was itself constituted of two domains, the internal one of which contained cellulose. The major pectin of both the water-soluble and adherent seed mucilage was rhamnogalacturonan I.

This study has only provided a rough indication of the composition of the mucilage of the diaspores investigated. The chemistry of mucilage is complex and needs a more detailed study to determine the exact type of polysaccharide-forming mucilage in each diaspore.

\section{CONCLUSIONS}

The mucilaginous layer of the diaspores of 12 species from Namaqualand was investigated anatomically using both light and scanning electron microscopy. The structural origin of the mucilage produced by the diaspores was diverse. Diaspores of myxospermic plant species might produce mucilage in different ways; but in general, this function resides in the epidermal cells and other external appendages such as hairs and wings. Previous systems to classify the different types of mucilage production did not recognize the mucilaginous nature of wings or pappus. Despite the diversity of the origin and structure of the mucilage, it performs more-or-less the same ecological functions.

\section{ACKNOWLEDGEMENT}

The authors gratefully acknowledge the support received from the German Federal Ministry of Education and Research (BMBF) through the BIOTA South Project and the National Research Foundation under grant no. 61277 .

\section{REFERENCES}

BREGMAN, R. \& GRAVEN, P. 1997. Subcuticular secretion by cactus seeds improves germination by means of rapid uptake and distribution of water. Annals of Botany 80: 525-531. 
CONSERVATION INTERNATIONAL. 2009. http://www.biodiversityhotspots.org (accessed 2009).

CHAMBERS, J.J. \& MACMAHON, J.A. 1994. A day in the life of a seed: movements and fates of seeds and implications for natural and managed systems. Annual Review of Ecology and Systematics 25: 263-392.

ELLNER, S. \& SHMIDA, A. 1981. Why are adaptations for long-range seed dispersal rare in desert plants? Oecologia 51: 133-144.

FOTOUO MAKOUATE, H. 2008. Dispersal strategies in communal versus privately-owned rangeland in Namaqualand, South Africa. M.Sc. dissertation, University of Pretoria, Pretoria.

GAT-TILMAN, G. 1995. The accelerated germination of Carrichtera annua seeds and the stimulating and inhibiting effects produced by the mucilage at supra-optimal temperatures. Journal of Arid Environments 30: 327-338.

GRUBERT, M. 1974. Studies on the distribution of myxospermy among seeds and fruits of Angiospermae and its ecological importance. Acta Biologica Venezuelica 8: 315-351.

GUTTERMAN, Y. 1993. Seed germination in desert plants. Springer, Berlin.

GUTTERMAN, Y. 1996. Some ecological aspects of plant species with mucilaginous seed coats inhabiting the Negev Desert of Israel. In Y. Steinberg, ed., Preservation of our world in the wake of change 6: 492-496. Jerusalem.

GUTTERMAN, Y. \& SHEM-TOV, S. 1997. Mucilaginous seed coat structure of Carrichtera annua and Anastatica hierochuntica from the Negev Desert highlands of Israel and its adhesion to the soil crust. Journal of Arid Environments 35: 695-705.

GUTTERMAN, Y., WITZTUM, A. \& EVENARI, M. 1967. Seed dispersal and germination in Blepharis persica (Burm.) Kuntze. Israel Journal of Botany 16: 213-234.

GUTTERMAN, Y., WITZTUM A. \& HEYDECKER, W. 1973. Studies of the surfaces of desert plant seeds. II. Ecological adaptations of the seeds of Blepharis persica. Annals of Botany 37: 1051-1055.

HEDGE, I.C. 1970. Observation on the mucilage of Salvia fruits. Notes from the Royal Botanic Garden Edinburgh 30: 79-95.

HUANG, Z., BOUBRIAK, I., OSBORNE, D.J., DONG, M. \& GUTTERMAN, Y. 2008. Possible role of pectin-containing mucilage and dew in repairing embryo DNA of seeds adapted to desert conditions. Annals of Botany 101: 277-283

LAWTON, J.R. \& ETTRIDGE, S.C. 1986. Cytochemical staining of lipids in transition electron microscopy. Electron Microscopy Society of Southern Africa Proceedings 16: 115, 116.

LEPRINCE, O., HENDRY, G.A.F. \& MCKENZIE, B.D. 1993 Membranes, protection, desiccation and ageing. Seed Science Research 3: 272-275.

MACQUET, A., RALET, C.-C., KRONENBERGER, J., MARIONPOLL, A. \& NORTH, H.M. 2007. In situ chemical and macromolecular study of the composition of Arabidopsis thaliana seed coat mucilage. Plant Cell Physiology 48: 984-999.
MCLEAN, W.C. \& IVIMEY COOK, W.C. 1941. Plant science formulae. A reference book for plant science laboratories (including Bacteriology). MacMillan, London.

MUCINA, L. \& RUTHERFORD, M.C. (eds). 2006. The vegetation of South Africa, Lesotho and Swaziland. Strelitzia 19. South African National Biodiversity Institute, Pretoria.

MURBECK, S. 1919. Beiträge zur Biologie der Wüstenpflanzen: Vorkommen und Bedeutung von Schleimabsonderung aus Samenhüllen. Lunds Universitats Arsskrif NF Adv 2, 15: 1-36.

O'BRIEN, T.P. \& MCCULLY, M. 1981. The study of plant structure. Principles and selected methods. Termarcarphi, Melbourne.

OSBORNE, D.J., SHARON, R. \& BEN-ISHAI, R. 1980/81. DNA integrity and repair. Israel Journal of Botany 29: 259-272.

RÖSCH, M.W. 1977. Enkele plantekologiese aspekte van die Hester Malan-natuurreservaat. M.Sc. dissertation. University of Pretoria, Pretoria.

STOPP, K. 1958. Die verbreitungshemmenden Einrichtungen in der südafrikanischen Flora. Botanische Studien 8, Jena.

TAMARA, L.W., SKINNER, D.J. \& HAUGHN, G.W. 2000. Differentiation of mucilage secretory cells of Arabidopsis seed coat. Plant Physiology 122: 345-355.

VAN DER MERWE, C.F. \& PEACOCK, J. 1999. Enhancing conductivity of biological material for the SEM. Microscopy Society of Southern Africa-Proceedings 29: 44.

VAN RHEEDE VAN OUDTSHOORN, K. \& VAN ROOYEN, M.W. 1999. Dispersal biology of desert plants. Springer, Berlin.

VAN ROOYEN, M.W., THERON, G.K. \& GROBBELAAR, N. 1990. Life form and dispersal spectra of the flora of Namaqualand, South Africa. Journal of Arid Environments 19: 133-145.

VAN ROOYEN, M.W. 1999. Functional aspects of short-lived plants. In R.W.J. Dean \& S.J. Milton (eds), The Karoo: ecological patterns and processes: pp. 107-122. Cambridge University Press, Cambridge.

WINDSOR, J.B., SYMONDS, V.V., MENDENHALL, J. \& LLOYD, A.M. 2000. Arabidopsis seed coat development: morphological differentiation of the outer integument. Plant Journal 22: 483-493.

WILLATS, W.G.T., MCCARTNEY, L. \& KNOX, J.P. 2001. In situ analysis of pectic polysaccharides in seed mucilage and at the root surface of Arabidopsis thaliana. Planta 213: 37-44.

ZAADY, E., GUTTERMAN, Y. \& BOEKEN, B. 1997. The germination of mucilaginous seeds of Plantago coronopus, Reboudia pinna$\mathrm{ta}$, and Carrichtera annua on cyanobacterial soil crust from the Negev. Plant and Soil 190: 247-252.

ZOHARY, M. 1937. Die verbreitungsökologischen Verhältnisse der Pflanzen Palästinas. Die antitelechoristischen Erscheinungen. Beihefte Botanisches Centralblatt A 56: 1-155. 